\title{
Occurrence of Sclerotinia Foliage Blight Disease of Cucumber and Pepper Plants under Protected Cultivation System in Egypt I. Chemical and Biological Control Measures in Vitro
}

\author{
M. M. Abdel-Kader, Nehal S. El-Mougy ${ }^{*}$, E. I Embaby, S. M. Lashin \\ Plant Pathol. Dept., National Research Centre, Giza, Egypt
}

\begin{abstract}
During the winter season 2011, a sever Sclerotinia blight disease symptoms were observed on cucumber and Pepper plants grown in the Protected Cultivation Station, Ministry of Agriculture located at Tookh province, Qalubiya governorate, Egypt. Surveyed plastic houses at the previous location revealed that the recorded Sclerotinia blight disease incidence was 2.8 and 3.3\% for cucumber and pepper plants, respectively. The isolated causal pathogens for cucumber and pepper foliage blights were identified as Sclerotinia sclerotiorum (Lib.) de Bary and S. minor Jagger, respectively. This is thought to be the first report of these fungi to cause foliage blights on cucumber and pepper in Egypt. As control measures antagonistic agents and fungicides against the growth both pathogenic fungi under in vitro conditions were evaluated. The obtained results showed complete growth inhibition was recorded for both S. sclerotiorum and S. minor at 100ppm of Topsin-M and Ridomil Gold, while Rizolex-T gave the same effect at 200ppm. The fungicide, Previcure had inhibitor effect on the mycelia growth of both fungi only at the high concentration $800 \mathrm{ppm}$. Moreover, the antagonistic fungi (Trichoderma spp.) showed superior inhibitory effect against the growth of pathogenic fungi compared with bacterial isolates (B. subtilis $\&$ P. florescence). No significant differences between the tested antagonistic microorganisms and commercial biocides were observed.
\end{abstract}

Keywords Antagonistic Agents, Cucumber, Foliage Blight Disease, Fungicides, Pepper, Pseudomonas Fluorescens, Sclerotinia Sclerotiorum, S. Minor, T. Harzianum, T. Viride

\section{Introduction}

Cucumber and pepper crops are cultivated throughout the world as important vegetables or a food source. In Egypt, most vegetable crops except potato are cultivated in the plastic-house conditions during the winter season. The plastic-house conditions are favorable for occurrence of fungal diseases on the crops due to the high humidity. Especially, Sclerotinia rot is apt to readily occur under cool and moist conditions[1,2]. Severe outbreaks of stem or fruit rot symptoms with sclerotial formation were observed during a disease survey of vegetable crops in the Protected Cultivation Station, Ministry of Agriculture located at Tookh province, Qalubiya governorate, Egypt during the cool season 2011. The disease was recorded as Sclerotinia stem rot, Sclerotinia fruit rot, fruit and stem rot, fruit rot, stem blight and rot, white mold or pink joint depending on the species of the

* Corresponding author:

nehal_nrc@yahoo.com (Nehal S. El-Mougy)

Published online at http://journal.sapub.org/ als

Copyright (C 2012 Scientific \& Academic Publishing. All Rights Reserved infected crops[3]. It has been reported that Sclerotinia sclerotiorum (Lib.) de Bary and S. minor Jagger cause Sclerotinia rot in a variety of plants[1,3-5]. Some mycological and pathological characteristics of $S$. sclerotiorum and $S$. minor causing Sclerotinia rot of vegetable crops were also reported[6]. As control measures, chemical fungicides are successfully reported to control Sclerotinia spp.

In this regards, it was reported that among the fungicides tested, the most effective fungicides in inhibiting the sclerotial germination were Ridomil gold, Benlate, Tecto-60 and Topsin-M[7]. Also, In vitro test, Rizolex-T and Topsin-M at $200 \mathrm{ppm}$ was completely inhibited the growth of $R$. solani and $F$. oxysporum, respectively[8], meanwhile among the fungicides tested, Ridomil MZ 72 WP (metalaxyl 8\%+ mancozeb $64 \% \mathrm{WP}$ ) was found to give the best protection against Sclerotinia root rot incidence in both common and Tartary buckwheat (by 50 and $56 \%$ protection of root rot incidence over the control, respectively) and thereby increased the plant stand[9].

Some successes have been recorded using biological methods of control. These have included the application of specific fungal antagonists such as Coniothyrium minitans; 
Sporidesmium sclerotivorum and Trichoderma hamatum $[10$, 11], as well as inoculation into the rhizosphere of nonspecific fungal antagonists such as Trichoderma and Gliocladium species[12]. Both specific and nonspecific fungal antagonists have been reported to actively parasitize sclerotia, mycelia and ascospores of several Sclerotinia species[13]. The activity of the antagonistic fungi Coniothyrium minitans and Trichoderma hamatum against Sclerotinia spp. in both laboratory and greenhouse assays was reported[14]. Although other studies have been conducted to determine the effects of chitinolytic fungi and bacteria on the growth and development of a number of soilborne fungal pathogens [15, 16]. Also, three isolates, Serratia marcescens, Streptomyces viridodiasticus and Micromonospora carbonacea, significantly reduced the growth of $S$. minor in vitro, and produced high levels of chitinase and b-1,3-glucanase[17]. Moreover, it was reported that [18] four bacterial strains, Pseudomonas chlororaphis, Bacillus amyloliquefaciens, Pseudomonas sp. and B. amyloliquefaciens had been found to have biocontrol activity in vitro assays against Sclerotinia sclerotiorum, the causal agent of stem rot of canola.

Few studies have been conducted on the detailed characteristics of the disease occurrence and the pathogenicity of the causal Sclerotinia species on different crops. Therefore, this study was conducted to reveal trends of the disease occurrence on cucumber and pepper crops in Egypt, the pathological aspects of the causal Sclerotinia spp. as well as the efficacy of some biological and chemical measures for controlling Sclerotinia spp. under laboratory conditions.

\section{Materials and Methods}

\subsection{Disease Survey}

The most reported areas for high production of vegetables under protected cultivation system in Egypt were subjected to survey the infected plants with Sclerotina foliage blight. The surveyed plants were Cucumber, Pepper, Tomato and Cantaloupe. The percentage diseases incidence was recorded at different commercial greenhouses distributed in five governorates, i.e. Giza, Cairo, Kalubia, Ismaelia and Behiera. The average percentages of plant infections were calculated as the number of infected plants in relative to the total number of examined plants.

\subsection{Isolation Trails}

Plant samples showing Sclerotinia foliage blight symptoms were collected and subjected to isolation trails. Sclerotinia spp. were isolated from the lesions appeared on diseased plants. Lesion pieces $\left(2-3 \mathrm{~cm}^{2}\right)$ cut from the diseased plant parts were placed on $2 \%$ water agar (WA) after surface-sterilizing with $1 \%$ sodium hypochlorite solution for 1 minute. The plates were incubated for $1 \sim 2$ days at $22^{\circ} \mathrm{C}$. The fungi grown from the lesion pieces were transferred to potato dextrose agar (PDA) slants and cultured for identification. Identification for the isolated fungi were carried out ac- cording to[19,20].

\subsection{Pathogenicity Test}

Pathogenic ability of S. sclerotiorum and S. minor to induce foliage blight infection of cucumber and sweet pepper seedlings was tested under greenhouse conditions. Two cultivars each of Cucumber (D.P $162 \&$ Hisham) and sweet pepper (Capsicum annuum L.) Khyrratte \& Kaha were used for pathogenicity test. Transplants (5 weeks-old) were sown in plastic pots $(25 \mathrm{~cm}$ in diameter) filled with sterile soil containing loamy soil artificially infested individually (at the rate of $5 \% \mathrm{w}: \mathrm{w})$ with the inoculum of each tested isolate which previously grown for two weeks on sand barley medium (1:1, w:w and $40 \%$ water). Then, the pots were placed in a dew chamber with $100 \%$ relative humidity at $22^{\circ} \mathrm{C}$ for 48 $\mathrm{hr}$ and then moved into the greenhouse. Three pots each containing five transplants were used as replicates for each tested isolate as well as control. Disease incidence was rated based on the degree of rot symptoms induced 30 days after transplanting as the following scale:

(-) no lesion observed;

(+) $0.5-1 \mathrm{~cm}$ rot lesion on stem above the soil surface;

$(++) 2-3 \mathrm{~cm}$ rot lesion or wholly rotted stem above the soil surface.

\subsection{Laboratory Control Measures}

\section{I: Sensitivity test against fungicides}

The inhibitory effect of four fungicides against the $S$. sclerotiorum and $S$. minor fungal growth was evaluated under in vitro conditions. The fungicides, Ridomil (a.i. 2,6 dimethyl phenyl-metalaxy acetylamoni-propionic acid methyl ester 47\%), Topsin- M (a.i. Thiophanate-Methyl $70 \%$ ), Rizolex-T (a.i. Tolclofos-methyl 50\%) and previcure (a.i. Propamocarb hydrochloride $72.2 \%$ ) were tested. Eight concentrations of each fungicide, i.e. 50,100,200,400 and $800 \mathrm{ppm}$ based on the active ingredient were prepared in PDA medium poured in Petri-dishes. Control treatment was fungicide-free medium. Petri-dishes were inoculated with $5 \mathrm{~mm}$ disc of 10-day-old tested fungal cultures. Three replicates were used for each particular treatment as well as control. All previous plates were incubated at $25 \pm 1^{0} \mathrm{C}$ for 7 days then examined. Average linear growth was measured and percentage of growth reduction was calculated in relative to that grown in control treatment.

\section{II: Sensitivity test against antagonistic microorganisms}

The inhibitory effect of the isolated fungal and bacterial antagonistic agents against the linear growth of S. sclerotiorum and $S$. minor fungi was evaluated using the modified dual culture technique[19]. The antagonistic microorganisms, i.e. Trichoderma harzianum, T. viride, T. hamatum, Bacillus subtilis and Pseudomonas fluorescens, were obtained from the Plant Pathology Department of the National Research Centre, Giza, Egypt. These microorganisms were isolated from the rhizosphere of various healthy and root rot infected leguminous crops, grown in the Delta and Middle Egypt regions, and proved their high pathogenic or antago- 
nistic ability during previous work at the same department. Fungal and bacterial cultures were maintained on potato dextrose agar (PDA) and nutrient agar slant media at $5 \pm 1^{\circ} \mathrm{C}$ as stock cultures until use. All isolates were refreshed by growing at the optimum growth conditions at the beginning of the present tests. In vitro antagonistic studies of biocontrol microorganisms and pathogenic fungi were performed on PDA medium in 9-cm-diameter Petri dishes. The commercial biocides products, e.g. Plant guard, Biocure-F, Biocure$\mathrm{D}$, Rhizo-N were also tested against pathogenic fungi as a reference to the present tested antagonistic microorganisms. The control treatment was inoculated with a culture disk of either a pathogenic or antagonistic culture alone at the same conditions. All inoculated Petri dishes were incubated at $28 \pm 1^{\circ} \mathrm{C}$ for five days, then the antagonistic effect was measured. This test was repeated five times and the growth inhibition was calculated as the percentage reduction in colony growth diameter of pathogenic fungi in the presence of antagonistic microorganism in relative to their growth in control treatment.

\section{Statistical analysis}

All experiments were set up in a complete randomized design. One-way ANOVA was used to analyze differences between inhibitor effect and linear growth of pathogenic fungi in vitro. A general linear model option of the analysis system SAS[21 was used to perform the ANOVA. Duncan's multiple range test at $\mathrm{P}<0.05$ level was used for means separation [22].

\section{Results and Discussion}

\subsection{Disease survey}

Sclerotinia foliage blight occurred in cucumber and pepper plants grown under protected cultivation system at Tookh location at Kalubia governorate, Egypt (Table 1). Occurrence of the disease was observed in 18 out of 28 surveyed plastic houses during the growing winter season, 2011. The mean of disease severely occurred as high as $3.4 \%$ in pepper and as low as $2.8 \%$ in cucumber plants.

Table 1. Survey of scelrotinia foliar diseases of cucumber and pepper plants grown under protected cultivation system at Tookh location at Kalubia governorate, 2011

\begin{tabular}{|c|c|c|c|c|}
\hline \multirow{2}{*}{ Host plant } & $\begin{array}{c}\text { Cultivar } \\
\text { variety }\end{array}$ & $\begin{array}{c}\text { No. of sur- } \\
\text { veyed plastic } \\
\text { house }\end{array}$ & $\begin{array}{c}\text { Sclerotinia } \\
\text { foliar blight \% }\end{array}$ & Mean \\
\hline \multirow{3}{*}{ Cucumber } & Hisham & 4 & $2.8 \mathrm{ab}$ & \multirow{3}{*}{2.8} \\
\cline { 2 - 4 } & D.P. 162 & 4 & $3.1 \mathrm{~b}$ & \multirow{2}{*}{3.4} \\
\cline { 2 - 4 } & Hykal & 4 & $2.4 \mathrm{a}$ & \\
\hline \multirow{2}{*}{ pepper } & Khyrratte & 3 & $3.5 \mathrm{c}$ & \\
\cline { 2 - 4 } & Kaha & 3 & $\mathrm{~b}$ & \\
\hline
\end{tabular}

Mean values within columns followed by the same letter are not significantly different $(\mathrm{P} \leq 0.05)$

Data also showed variation in disease incidence between cultivated varieties. Cucumber cv. Hisham significantly expressed as the highest susceptible cultivar to disease infection followed by D.P.162 and Hykal cvs., respectively.
Meanwhile, no significant differences were observed between the two monitored pepper cultivars. Disease symptoms on cucumber (Fig. 1, a) become visible on plant branches, leaves, flowers and fruits. In a cool moist environment, which normally provided under greenhouses conditions, watery soft lesions occur at sites of infection and the tissues are rapidly covered with white fluffy mycelium. The leaves become chlorotic and necrotic, and stems become girdled and die. On the dead plant tissue, as well as within tissue such as stems and fruits, fungal sclerotia are formed. The causal fungus was isolated and identified as Sclerotinia sclerotiorum (Lib.) de Bary. According to the available literatures, this is thought to be the first record of Sclerotinia blight disease of cucumber in Egypt. Meanwhile, disease symptoms on pepper appeared as brown lesions formed at the apical part of branches in affected plants. These lesions may expand and girdle the twigs, therefore, bud wilt and twig death follow. A cottony white mycelium develops around diseased areas with black irregularly shaped sclerotia, also watery soft rot of formed fruits take place (Fig. 1, b). The causal fungus was isolated and identified as Sclerotinia minor Jagger. According to the available literatures, this is thought to be the first record of Sclerotinia foliage blight disease of pepper in Egypt. Disease symptoms on cucumber (Fig. 1, a) become visible on plant branches, leaves, flowers and fruits. In a cool moist environment, which normally provided under greenhouses conditions, watery soft lesions occur at sites of infection and the tissues are rapidly covered with white fluffy mycelium.

The leaves become chlorotic and necrotic, and stems become girdled and die. On the dead plant tissue, as well as within tissue such as stems and fruits, fungal sclerotia are formed. The causal fungus was isolated and identified as Sclerotinia sclerotiorum (Lib.) de Bary. According to the available literatures, this is thought to be the first record of Sclerotinia blight disease of cucumber in Egypt. Meanwhile, disease symptoms on pepper appeared as brown lesions formed at the apical part of branches in affected plants. These lesions may expand and girdle the twigs, therefore, bud wilt and twig death follow. A cottony white mycelium develops around diseased areas with black irregularly shaped sclerotia, also watery soft rot of formed fruits take place (Fig. $1, \mathrm{~b})$. The causal fungus was isolated and identified as Sclerotinia minor Jagger. According to the available literatures, this is thought to be the first record of Sclerotinia foliage blight disease of pepper in Egypt.

In this regard, Sclerotinia stem rot of pepper has been reported in Florida, Iowa, Texas, Massachusetts and Connecticut and this was considered the first report of the disease on pepper in Ohio in 1992[24]. Sclerotinia foliar blights was the first report of bell pepper as a host of $S$. minor in the Salinas Valley, California, USA, at 1997[25] and also, the first report of S. sclerotiorum on cucumbers in Iran was recorded during autumn 1997[26], in greenhouses the disease infection of pepper plants with pathogen S. sclerotiorum increases during favorable conditions and could infect pepper flower causing flowers and bud rots[27]. Fur- 
thermore, Sclerotinia blights, caused by Sclerotinia sclerotiorum is also reported on different host plants, i.e. beans, peanuts and occasionally on chilli plants[28,29].

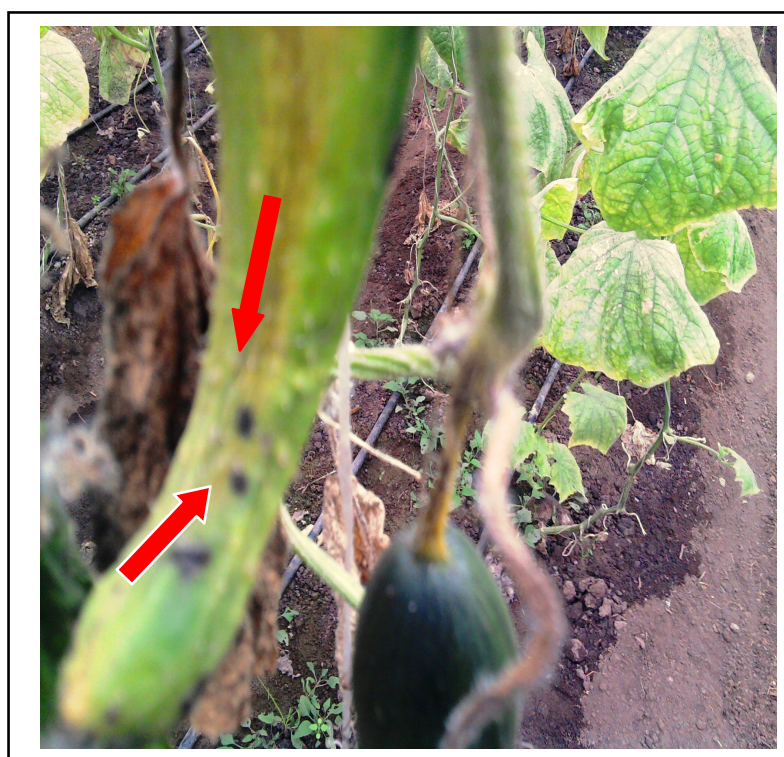

(a)

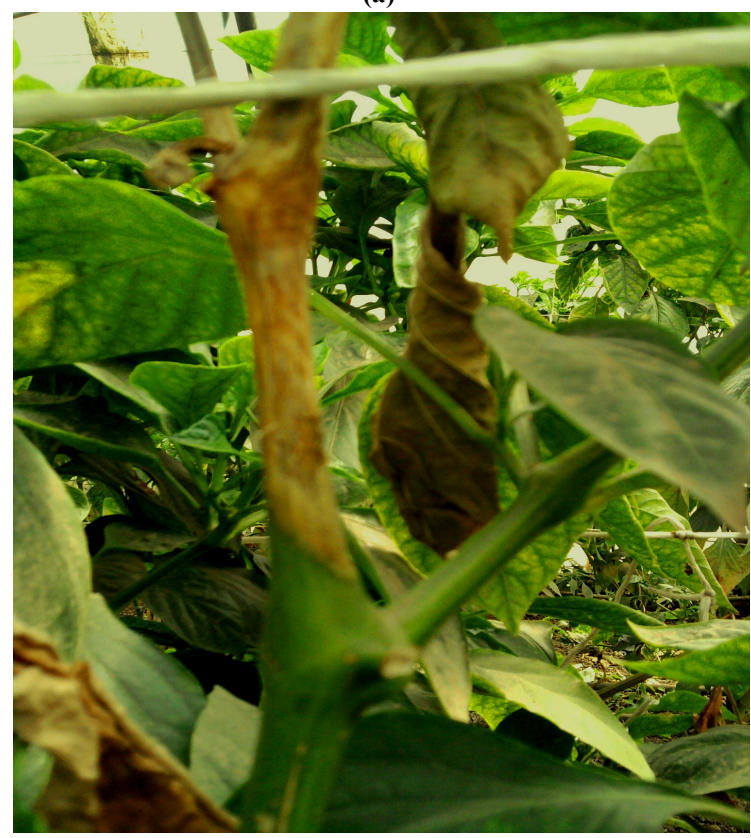

(b)

Figure 1. Typical symptoms of natural infection with Sclerotinia foliage blight disease of cucumber (a) and pepper (b) plants grown under protected cultivation system

\subsection{Pathogenicity Test}

Isolation from the collected cucumber and pepper samples showing foliage blight symptoms resulted in two species of the fungus Sclerotinia. The identified fugal species were $S$. sclerotiorum and $S$. minor. Pathogenicity test for these fungi revealed that they are able to induce foliage blight symptoms of either cucumber and pepper plants (Table 2).

Data also show that there was no significant difference between the two fungi either for host or their cultivars tested. Data also showed that $S$. sclerotiorum was more aggressive for inducing the disease infection than S. minor for both host plants and consequently their cultivar varieties.

The soil-borne plant pathogens Sclerotinia sclerotiorum and $S$. minor cause severe economic losses of many vegetable and ornamental crops around the world. Sclerotinia sclerotiorum and $S$. minor have been reported to be the pathogen of Sclerotinia rot of various crops[1,3,25].

In general, sclerotia of Sclerotinia spp. can survive in nature for many years [30] and play the important role as an inoculum source of the disease occurrence[2]. It has not yet been studied on the sclerotial density and viability of the two Sclerotinia spp. in the field of vegetable crops.

There have been reports on differences in virulence of $S$. sclerotiorum isolates to individual plants and in susceptibility of some plants to the isolates[6,31]. It has been also reported that there are differences in susceptibility of cultivars or lines of some crops to the pathogen[32,33]. However, the present study showed that there was no significant difference in virulence of $S$. sclerotiorum isolates to cucumber and pepper crops, as reported by previous workers in other crops[34,35].

On the other hand, S. minor was relatively less virulent on the two tested host plants cultivars than on another one, suggesting that there might be some differences in susceptibility of these cultivars to $S$. minor.

Table 2. Pathogenicity of Sclerotinia sclerotiorum and Sclerotinia minor on different cultivars of cucumber and pepper

\begin{tabular}{|c|c|c|c|c|}
\hline \multirow{2}{*}{$\begin{array}{l}\text { Host } \\
\text { plant }\end{array}$} & \multirow{2}{*}{$\begin{array}{l}\text { Cultivar } \\
\text { variety }\end{array}$} & \multicolumn{2}{|c|}{ Sclerotinia blight } & \multirow[b]{2}{*}{ Untreated control } \\
\hline & & $\begin{array}{l}\text { S. scle- } \\
\text { rotiorum }\end{array}$ & $\begin{array}{c}S . \\
\text { minor }\end{array}$ & \\
\hline \multirow{2}{*}{$\begin{array}{l}\text { Cucum- } \\
\text { ber }\end{array}$} & Hisham & ++ & + & - \\
\hline & D.P. 162 & ++ & + & - \\
\hline \multirow{2}{*}{ pepper } & Khyrratte & ++ & + & - \\
\hline & Kaha & ++ & + & - \\
\hline
\end{tabular}

(-) no lesion observed; $(+)$ 0.5-1 cm rot lesion on stem above the soil surface; $(++)$ 2-3 cm rot lesion or wholly rotted stem above the soil surface

\subsection{Laboratory Control Measures}

\section{I: Sensitivity test against fungicides}

The major value of any chemical compound as a disease control agent ultimately depends on the mode of action of the molecule at the physiological level on one or more components of the life cycle of the pathogen. Eruptive germination of sclerotia followed by mycelial growth occurs when $S$. minor and S. sclerotiorum initiate disease infection to plants. Suppression of these activities should reduce the capacity of these pathogens to cause disease in the field. Laboratory test of the fungicidal effect against S. sclerotiorum and S. minor is a simple approach for understanding a small sector of chemical system on Sclerotinia foliage blight disease of cucumber and pepper plants caused by these pathogenic fungi. Data in Table (3) and figure (2) reveal that the reduction in the growth of both tested fungi was correlated to the increasing concentrations of either Rizolex-T, Topsin-M and Ridomil Gold in medium. Data also indicate that the two tested fungi varied in their sensitivity against the fungicides used. Complete growth inhibition was recorded for both $S$. 
sclerotiorum and S. minor at 100ppm of Topsin-M and Ridomil Gold, while the same effect was recorded at 400ppm and 200ppm of Rizolex-T for both species of Sclerotinia, respectively. The growth of S. minor showed more positive response to Rizolex-T, Topsin-M and Ridomil Gold concentrations, than the growth of S. sclerotiorum. In this concern, significant decrease in mycelial growth and sclerotial production, of the fungus of $S$. sclerotiorum, with higher concentration of fungicide was recorded [7]. Mycelial growth was most sensitive to Benlate, Ridomil gold,
Tecto-60 and Topsin-M at both the concentrations of 100 and $200 \mathrm{ppm}$. Similar results concerning the inhibitor effect of Rizolex-T and Topsin-M at different concentrations against soilborne fungi, $R$. solani and $F$. oxysporum were also [36, 37, 38]. Furthermore, Rizolex-T could control root rot of cowpea caused by $R$. solani and $F$. solan $i$ when used as seed dressing or soil drench in solarized soil [39]. Also, lupine seeds dressing with recommended dose of Rizolex-T resulted in significant reduction in root rot incidence caused by $R$. solani, S. rolfsii and F. solani [40].

Table 3. Linear growth of S. sclerotiorum and S. minor in response to different concentrations of fungicides in vitro

\begin{tabular}{|c|c|c|c|c|c|c|c|c|c|c|}
\hline \multirow{4}{*}{ Fungicides } & \multicolumn{10}{|c|}{ Linear growth (mm) } \\
\hline & \multicolumn{5}{|c|}{ S. sclerotiorum } & \multicolumn{5}{|c|}{ S. minor } \\
\hline & \multicolumn{10}{|c|}{ Fungicides concentration (ppm) } \\
\hline & 50 & 100 & 200 & 400 & 800 & 50 & 100 & 200 & 400 & 800 \\
\hline Topsin- M & $6.3 \mathrm{ef}$ & $0.0 \mathrm{~g}$ & $0.0 \mathrm{~g}$ & $0.0 \mathrm{~g}$ & $0.0 \mathrm{~g}$ & $5.6 \mathrm{f}$ & $0.0 \mathrm{~g}$ & $0.0 \mathrm{~g}$ & $0.0 \mathrm{~g}$ & $0.0 \mathrm{~g}$ \\
\hline Rizolex-T & $28.3 \mathrm{~b}$ & $21.6 \mathrm{c}$ & $11.6 \mathrm{f}$ & $0.0 \mathrm{~g}$ & $0.0 \mathrm{~g}$ & $26.0 \mathrm{bc}$ & $21.6 \mathrm{c}$ & $0.0 \mathrm{~g}$ & $0.0 \mathrm{~g}$ & $0.0 \mathrm{~g}$ \\
\hline Ridomil Gold & $0.0 \mathrm{~g}$ & $0.0 \mathrm{~g}$ & $0.0 \mathrm{~g}$ & $0.0 \mathrm{~g}$ & $0.0 \mathrm{~g}$ & $9.6 \mathrm{de}$ & $0.0 \mathrm{~g}$ & $0.0 \mathrm{~g}$ & $0.0 \mathrm{~g}$ & $0.0 \mathrm{~g}$ \\
\hline Previcure & 90 a & $90 \mathrm{a}$ & 90 a & $90 \mathrm{a}$ & $16.6 \mathrm{de}$ & $90 \mathrm{a}$ & $90 \mathrm{a}$ & 90 a & $90 \mathrm{a}$ & $18.3 \mathrm{de}$ \\
\hline Control & 90 a & $90 \mathrm{a}$ & 90 a & $90 \mathrm{a}$ & $90 \mathrm{a}$ & $90 \mathrm{a}$ & 90 a & 90 a & $90 \mathrm{a}$ & $90 \mathrm{a}$ \\
\hline
\end{tabular}

Mean values within columns followed by the same letter are not significantly different $(\mathrm{P} \leq 0.05)$.

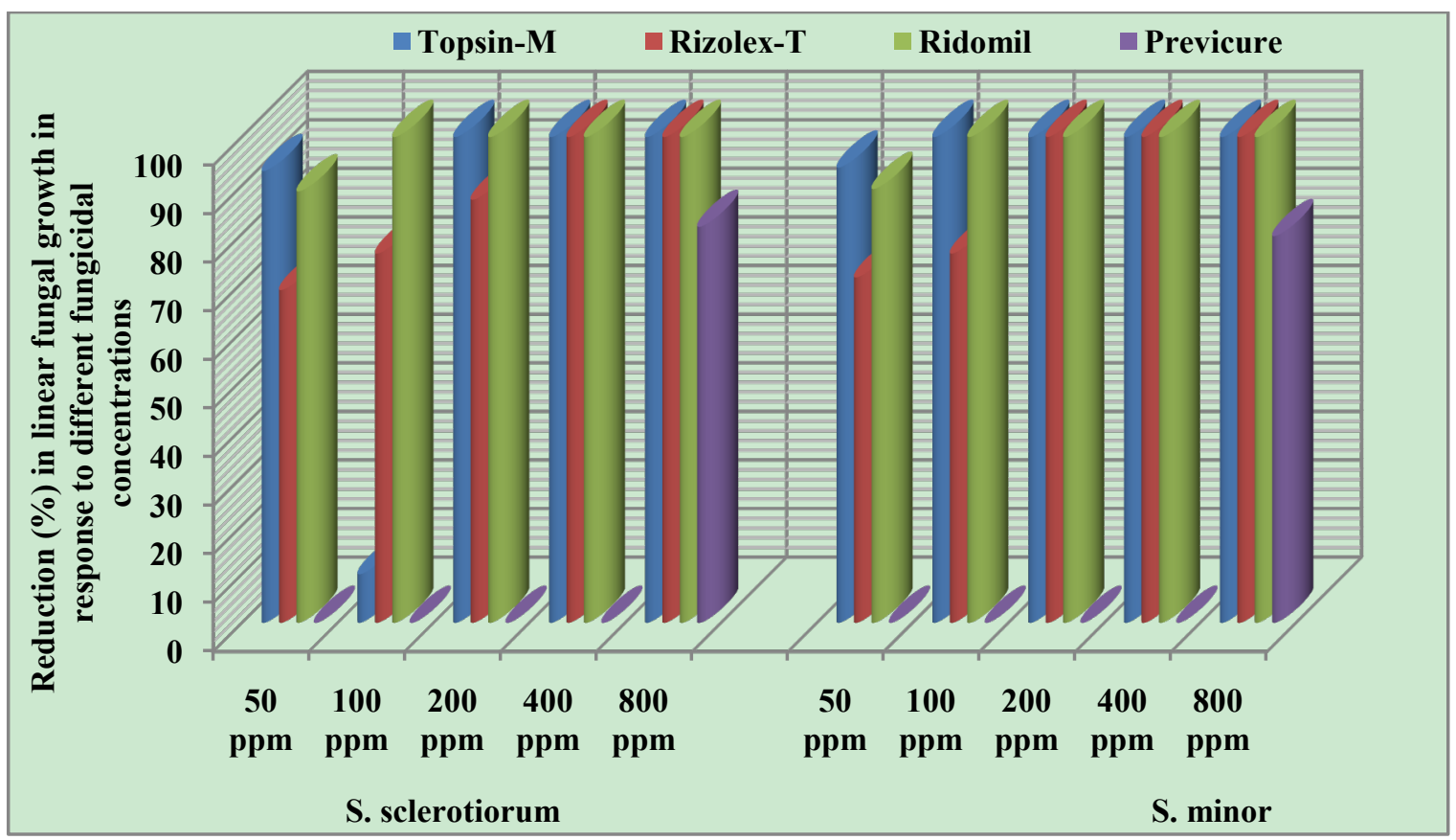

Figure 2. Reduction in linear fungal growth of S. sclerotiorum and S. minor in response to different concentrations of fungicides in vitro 
Data also, revealed interested observation that the fungicide Previcure had no inhibitor effect on the mycelia growth of both fungi which could be resistant to the fungicide. Only at concentration of $800 \mathrm{ppm}$ the linear growth of $S$. sclerotiorum and $S$. minor was recorded as 16.6 and $18.3 \mathrm{~mm}$. This observation had been explained by many workers. In vitro studies have been used to identify specific fungicides and rates for fungicidal activity against Sclerotinia spp.[41]. In addition, many isolates of Sclerotinia spp. must be evaluated to detect the presence of strains that express resistance to fungicides. Screening fungicides at different concentrations against many isolates can potentially identify fungicides that may have limited efficacy against Sclerotinia spp. In a previous study, no resistance to benomyl was detected within $100 \mathrm{~S}$. sclerotiorum isolates collected from a snap bean field treated with benomyl[42]. However, field isolates with resistance to fungicides have been reported in other Sclerotinia spp. affecting peanut (Arachis hypogaea L.) in Virginia (5) and lettuce (Lactuca sativa L.) in California[43]. The failure to control $S$. minor with fungicides in the field was attributed to fungicide resistant isolates[44].

\section{II: Sensitivity test against antagonistic microorganisms}

Antagonistic ability of various tested bio-agents represented in Table (4) revealed that all tested agents could drastically reduce the linear growth of root pathogenic fungi. The antagonistic fungi (Trichoderma spp.) showed superior inhibitory effect against the growth of pathogenic fungi compared with bacterial isolates (B. subtilis \& P. fluorescence). No significant differences between the tested antagonistic microorganisms and commercial biocides were observed. The antagonistic fungi had a greater significant effect on the retardation of growth (66.6-72.4\%) compared with the bacterial agents (50.4-58.7\%). The antagonistic bacteria also showed significant differences among the tested isolates.

Table 4. Growth reduction of Sclerotinia spp. in response to the inhibitor effect of antagonistic agents in vitro

\begin{tabular}{|c|c|c|}
\hline \multirow{2}{*}{ Antagonistic agent } & \multicolumn{2}{|c|}{ Fungal growth reduction \% ${ }^{*}$} \\
\cline { 2 - 3 } & S. sclerotiorum & S. minor \\
\hline T. harzianum & $72.6 \mathrm{a}$ & $70.4 \mathrm{a}$ \\
\hline T. viride & $72.4 \mathrm{a}$ & $70.6 \mathrm{a}$ \\
\hline T. hamatum & $68.6 \mathrm{ab}$ & $66.6 \mathrm{ab}$ \\
\hline B. subtilis & $57.6 \mathrm{~b}$ & $58.7 \mathrm{~b}$ \\
\hline P. fluorescens & $52.6 \mathrm{c}$ & $50.4 \mathrm{~d}$ \\
\hline Plant guard & $54.4 \mathrm{c}$ & $52.6 \mathrm{c}$ \\
\hline Bio Cure-F & $58.6 \mathrm{~b}$ & $54.6 \mathrm{c}$ \\
\hline Bio Cure-D & $56.4 \mathrm{~b}$ & $52.8 \mathrm{~cd}$ \\
\hline Rhizo-N & $52.2 \mathrm{~cd}$ & $50.4 \mathrm{~d}$ \\
\hline
\end{tabular}

Mean values within columns followed by the same letter are not significantly different $(\mathrm{P} \leq 0.05)$.

${ }^{*}$ The growth inhibition was calculated in relative to the growth in control treatment.

The highest inhibitory effect was recorded for $B$. subtilis. The commercial biocides products, e.g. Plant guard, Biocure-F, Biocure-D, Rhizo-N showed lesser effect in this regard. In the present study, the fungal and bacterial antagonists evaluated demonstrated an inhibitor effect against Sclerotinia spp. under in vitro conditions. These results are also confirmed by several researchers[10,12,14,17,45,46]. Also, it was recorded that an antagonistic bacterium strain BSH-4 (Bacillus pumilus) was isolated from rhizosphere soil of cucumber in the greenhouse. Dual culture test indicated that the strain was highly inhibitory to Sclerotinia sclerotiorum [47].

Microorganisms can play an enormously important role in plant disease control. As naturally occurring resident antagonists, they can be managed or exploited to achieve the desired results. Biological control with introduced microorganisms presents challenges not encountered with naturally occurring parasitic organisms. When used, natural enemies do not depend on the target pest as a host, which is the case with most antagonists of plant pathogens. Recent research on the use of introduced antagonists has to be considered in two ways: (i) antagonists, like the pathogen, should be adapted to the host plant to be protected, in addition to their ability to inhibit or compete with the target pathogen; and (ii) antagonists that can be applied directly and precisely to the infection court need not be able to spread or even persist in the environment. These two considerations for biological control sparked the current and much more successful effort with plant associated microorganisms as agents introduced for biological control of plant pathogens[48].

The promising obtained results in the present study could suggest that greater reductions in the incidence of Sclerotinia spp. foliar blights probably will require an integrated disease management approach, employing useful cultural, chemical and biological control methods as one component.

\section{ACKNOLEDGEMENTS}

This work was supported financially by the Science and Technology Development Fund (STDF), Egypt, Grant No. 1059.

\section{REFERENCES}

[1] Purdy, L. H., 1979, Sclerotinia sclerotiorum: History, diseases and symptomatology, host range, geographic distribution, and impact. Phytopathology, 69, 875-880

[2] Willetts, H. J., Wong, J.A.L., 1980, The Biology of Sclerotinia sclerotiorum, S. trifoliorum, and S. minor with emphasis on specific nomenclature. Bot. Rev., 46, 101-165

[3] Farr, D. F., Bills, G. F., Chamuris, G. P., Rossman, A. Y., Fungi on Plants and Plant Products in the United States. APS Press. The American Phytopathological Society, St. Paul, Minnesota, USA, (1989), $1252 \mathrm{pp}$

[4] Boland, G. J., Hall, R., 1994. Index of plant hosts of Sclerotinia sclerotiorum. Can. J. Plant Path., 16, 93-108

[5] Butzler, T. M., Bailey, J., Beute, M. K., 1998, Integrated Management of Sclerotinia Blight in Peanut: Utilizing Canopy Morphology, Mechanical Pruning, and Fungicide Timing. Plant Disease, 82, 1312-1318 
[6] Kim, W.G., Cho, W.D., Jee, H.J., 1999, Occurrence of Sclerotinia rot on cucurbitaceous vegetable crops in greenhouses. Korean J. Mycol., 27,198-205

[7] Iqbal, S.M., Ghafoor, A., Haqqani, A.M., 2003, Pathogenicity and Fungicidal Efficacy for Sclerotinia Rot of Brinjal. International Journal of Agriculture \& Biology, 4, 618-620

[8] Abdel-Kader, M.M., El-Bahr, M.K., El-Mougy, N.S., 2004, Pathogenic fungi and soil conditions causing root rot and wilt disease complex during acclimatization of tissue culture derived banana plantlets. Egypt. J. Phytopathol., 32, (1-2), $37-48$

[9] Mondal, K.K., 2004, Evaluation of seed-dressing fungicides against sclerotinia root rot of buckwheat. Fagopyrum, 21, 105-107

[10] Adams P.B., Ayers W.A., 1982, Biological control of Sclerotinia lettuce drop in the field by Sporidesmium sclerotivorum. Phytopathology, 72, 485-8

[11] Mischke, S., 1998, Mycoparasitism of selected sclerotia-forming fungi by Sporidesmium sclerotivorum. Canadian Journal of Botany, 76, 460-6

[12] Budge SP, Whipps JM, 1991. Glasshouse trials of Coniothyrium minitans and Trichoderma species for the biological control of Sclerotinia sclerotiorum in celery and lettuce. Plant Pathology 40, 59 \pm 66

[13] Whipps, J.M., Mcquilken, M.P., Budge, S.P., 1993, Use of fungal antagonists for biocontrol of damping-off and Sclerotinia diseases. Pesticide Science, 37, 309-313

[14] Rabeendran, N., Jones, F.E., Moot, D.J., Stewart, A., 2006, Biocontrol of Sclerotinia lettuce drop by Coniothyrium minitans and Trichoderma hamatum. Biological Control, 39, (3), 352-362

[15] Kazmar, E.R., Goodman, R.M., Grau, C.R., Johnson, D.W., Nordheim, E.V., Undersander, D.J., Handelsman, J.O., 2000, Regression analyses for evaluating the influence of Bacillus cereus on alfalfa yield under variable disease intensity. Phy topathology, 90, 657-665. doi: 10.1094/PHYTO.2000.90 .6 .657

[16] Whipps, J.M., Lumsden, R.D., 2001, Commercial use of fungi as plant disease biological control agents: status and prospects. In 'Fungi as biocontrol agents: progress, problems and potential'. (Eds TM Butt, C Jackson, N Magan) pp. 9-22. (CABI Publishing: Wallingford, UK)

[17] El-Tarabilya, K.A., Solimana, M.H., Nassara, A.H., Al-Hassania, H.A., Sivasithamparamc, K., McKennad, F., Hardy, G.E.St.J., 2000, Biological control of Sclerotinia minor using a chitinolytic bacterium and actinomycetes, Plant Pathology, 49, 573-583

[18] Fernando, W.G.D., Nakkeeran, S., Zhang, Y., Savchuk, S., 2007, Biological control of Sclerotinia sclerotiorum (Lib.) de Bary by Pseudomonas and Bacillus species on canola petals. Crop Protection, 26, 00-107

[19] Ferreira, J.H.S., Matthee, F.N., Thomas, A.C., 1991, Biological control of Eutypa lata on Grapevine by an antagonistic strain of Bacillus subtilis. Phytopathology, 81, 283-287

[20] Gilman, J.C., A manual of soil fungi. Iowa State University Press, Ames, Iowa, U.S.A., (1957) 450pp
[21] Barnett, H.L., Hunter, B.B., Illustrated genera of imperfect fungi. Burgess Publishing Company. Minneapolis, Minnesota, (1972), $241 \mathrm{pp}$

[22] SAS Institute Inc., 'SAS/STAT user's guide. Version 6. Vol. 2.' 12th edn. (SAS Institute Inc.: Cary, NC), (1996), 846 pp

[23] Winer B.J., 'Statistical principles in experimental design.' 2nd edn. (McGraw-Hill Kogakusha Ltd: Tokyo), (1971), 596 $\mathrm{pp}$

[24] Yanar, Y., Sahin, F., Miller, S.A., 1996, First report of stem and fruit rot of pepper caused by Sclerotinia sclerotiorum in Ohio. Plant Disease, 80, 3, 342

[25] Gonzalez, T.G., Henderson, D.M., Koike, S.T., 1998, First report of bell pepper (Capsicum annum) as a host of Sclerotinia minor in California, Plant Diseases, 58, 832

[26] Zakeri, Z., 1998, Sclerotinia rot in greenhouse grown cucumbers. Iranian Journal of Plant Pathology, 34, 3/4, 233-234

[27] Rista, L.M., Herzog, L.J., 2002, Greenhouse grown pepper Sclerotinia sclerotiorum petal infection, as affected by flowering stage (Infeccion de petalos por Sclerotinia sclerotiorum segun el estado de floracion en pimiento bajo invernadero). Revista FAVE - Ciencias Agrarias 1,(1), 65-70

[28] Lithourgidis, A.S., Tzavella-Klonari, K., Roupakias, D.G., 2003, The causal fungus of stem rot disease of faba beans in Greece. Journal of Phytopathology, 151, 11/12, 631-635

[29] Luong, T.M., Huynh, L.M.T., Le, T.V., Burgess, L.W., Phan, H.T., 2010, First report of Sclerotinia blight caused by Sclerotinia sclerotiorum in Quang Nam,Vietnam. Australasian Plant Disease Notes, 5, 1, 42-44

[30] Adams, P.B., Ayers, W.A., 1979, Ecology of Sclerotinia species. Phytopathology, 69, 896-899

[31] Price, K., Calhoun, J., 1975, Pathogenicity of isolates of Sclerotinia sclerotiorum (Lib.) de Bary to several hosts. Phytopathol. Z., 83, 232-238

[32] Orellana, R.G., 1975, Photoperiod influence on the susceptibility of sunflower to Sclerotinia stalk rot. Phytopathology, 65, 1293-1298

[33] Cassells, A.C., Walsh, M., 1995, Screening for Sclerotinia resistance in Helianthus tuberosus L. (Jerusalem artichoke) varieties, lines and somaclones, in the field and in vitro. Plant Pathology, 44, 428-437

[34] Kim, W.G., Cho, W.D., 2002, Occurrence of Sclerotinia rot on composite vegetable crops and the causal Sclerotinia spp. Mycobiology, 30, 41-46

[35] Kim, W.G. Cho, W.D., 2003, Occurrence of Sclerotinia rot in cruciferous crops caused by Sclerotinia spp. Plant Pathol. J., $19,69-74$

[36] Abdel-Kader, M. M., 1997, Field application of Trichoderma harzianum as biocide for control bean root rot disease. Egypt. J. Phytopathol., 25, 19-25

[37] Abdel-Kader, M.M., 1999, Biological and chemical control of wilt disease of hot pepper (Capsicum annum L.). Egypt. J. Phytopathol., 27,1-8

[38] Ragab, M.M., Aly, M.D.H., Ragab, M.M.M., El-Mougy, N.S., 1999, Effect of fungicides, biocides and bioagents on con- 
trolling of pea root rot disease. Egypt. J. Phytopathol., 27, $65-81$

[39] Abdel-Kader, M.M., Ashour, A.M.A., 1994, Chemical control of lupin wilt disease in solarized soil. Proc. of $7^{\text {th }}$ Congr. phytopathol., Egypt, pp.363-367

[40] Abd-El-Kareem, F., Abd-Alla, M.A., El-Gamal, N.G., El-Mougy, N.S., 2004, Integrated Control of Lupin Root Rot Disease in Solarized Soil under Greenhouse and Field Conditions. Egypt. J. Phytopathol., 32, (1-2), 49-63

[41] Hawthorne, B.T., Jarvis, W.R., 1973, Differential activity of fungicides on various stages in the life cycle of Sclerotinia spp. N.Z. J. Agric. Res., 16,551-557

[42] Hunter, J.E., Abawi, G.S., Crosier, D.C., 1978, Effects of timing, coverage, and spray oil on control of white mold of snap bean with benomyl. Plant Dis. Rep., 62,633-637

[43] Hubbard, J. C., Subbarao, K. V., and Koike, S. T. 1997. Development and significance of dicarboximide resistance in Sclerotinia minor isolates from commercial lettuce fields in California. Plant Dis. 81:148-153
[44] Hubbard, J.C., Subbarao, K.V., Koike, S.T., 1997, Development and significance of dicarboximide resistance in Sclerotinia minor isolates from commercial lettuce fields in California. Plant Dis., 81,148-153

[45] Menendez, A.B., Godeas, A., 1998, Biological control of Sclerotinia sclerotiorum attacking soybean plants: Degradation of the cell wall of this pathogen by Trichoderma harzianum (BAFC 742). Mycopathologia, 142, 153-60

[46] El-Mougy, N.S., Abdel-Kader, M.M., 2008, Long Term Activity of Bio-priming Seed Treatment for Biological control of Faba Bean Root Rot Pathogens. Australian Plant Pathology, 37, 464-471

[47] Yu, T., Pan, J., Che, Y., Mu, W., Liu, F., 2009, Biocontrol of bacterium strain BSH-4 against cucumber sclerotial blight and its identification. Acta Phytopathologica Sinica, 39, $425-430$

[48] Mathre, D.E., Cook, R.J., Callan, N.W. 1999, From discovery to use: traversing the world of commercializing biocontrol agents for plant disease control. Plant Disease, 83, 972--983. doi: 10.1094/PDIS.1999.83.11.972 